\title{
FIRST RECORD OF GZHELIAN FUSULINACEANS FROM THE CARBONIFEROUS OF NORTHERN SPAIN
}

\author{
Elisa VILLA' and Adriaan C. van GINKEL ${ }^{2}$ \\ ' Departamento de Geología, Universidad de Oviedo. 33005 Oviedo, Spain. \\ 2 Nationaal Natuurhistorisch Museum. 2300 RA Leiden, The Netherlands.
}

Villa, E. and Ginkel, A.C. van. 1999. First record of Gzhelian fusulinaceans from the Carboniferous of northern Spain.[Primer hallazgo de fusulináceos gzhelienses en el Carbonífero del norte de España]. Revista Española de Paleontología, no extr. Homenaje al Prof. J. Truyols, 205-216. ISSN 0213-6937.

\begin{abstract}
Several fusulinacean species of Gzhelian age have been found in a section close to the village of Asiego, in the northern part of Picos de Europa Massifs (Cantabrian Mountains). These specimens, which were collected in limestone beds from the upper part of the Puentellés Formation, belong to the genera Triticites, Rauserites, Jigulites, Ferganites and Quasifusulina and are the youngest fusulinaceans recorded in the Carboniferous of the Cantabrian Mountains. Among these microfaunas, Jigulites sp. bears the main stratigraphic significance since the Jigulites species are considered to be restricted to the Gzhelian stage. Therefore, the discovery of these species proves the presence of Gzhelian marine deposits in the area.
\end{abstract}

Keywords: Fusulinaceans, Gzhelian, Cantabrian Mountains, Spain.

\section{RESUMEN}

En las proximidades de Asiego, localidad situada al norte de los Picos de Europa (Cordillera Cantábrica, Norte de España), se han hallado en varias capas de calizas, atribuidas a la parte alta de la Formación Puentellés, diversas especies de fusulináceos pertenecientes a los géneros Triticites, Rauserites, Jigulites, Ferganites y Quasifusulina. De todas las formas encontradas, Jigulites sp. es la más significativa desde el punto de vista estratigráfico, dado que las especies de este género poseen una distribución restringida al Gzheliense.

En conjunto, las microfaunas de Asiego presentan rasgos que las convierten en los fusulináceos más jóvenes encontrados hasta el momento en el Carbonífero de la Cordillera Cantábrica y constituyen la prueba de la existencia de depósitos marinos del Gzheliense en esta área.

Palabras clave: Fusulináceos, Gzheliense, Cordillera Cantábrica, España.

\section{INTRODUCTION}

The Carboniferous of the Cantabrian Zone (Lotze, 1945) (Fig. 1) comprises thick successions of sedimentary rocks whose age ranges from Tournaisian to Kasimovian. These deposits have been studied in detail since the early fifties and so their stratigraphy and fossil content are, in general, well-known. The exception, however, is the youngest marine deposits of the so-called Gamonedo-Cabrales area, situated in the northern part of the Picos de Europa unit (Fig. 1), which only recently has become the focus of intensive attention.

The Gamonedo-Cabrales area is a sector of the Cantabrian Zone of special interest because it preserves late Hercynian synorogenic and postorogenic successions. However, the complex structure of the area is still under study, and the fusulinid associations in the limestone beds are important clues to unravel its tectonic history.
The uppermost Carboniferous strata of this area are the Puentellés (Martínez García, 1981) and Cavandi formations (Martínez García and Wagner, 1971). The Puentellés Formation rests unconformably on older Carboniferous rocks and includes thick limestone beds. The overlying Cavandi Formation consists of siliciclastic turbidites. The Puentellés Formation bears much higher interest for palaeontological and biostratigraphic studies, because the fossils in the Cavandi Formation are reworked.

At its type section (near Panes), the Puentellés Formation consists of two parts: the lower part is a succession of shales and sandstones, including a coalseam, and marks the unconformable boundary between this and the underlying Picos de Europa Formation; the upper part consists of some $400 \mathrm{~m}$ of limestones and argillaceous limestones, usually fine-grained and darkcoloured. According to Martínez García and Rodríguez Fernández (1984), the Puentellés Formation thins towards 

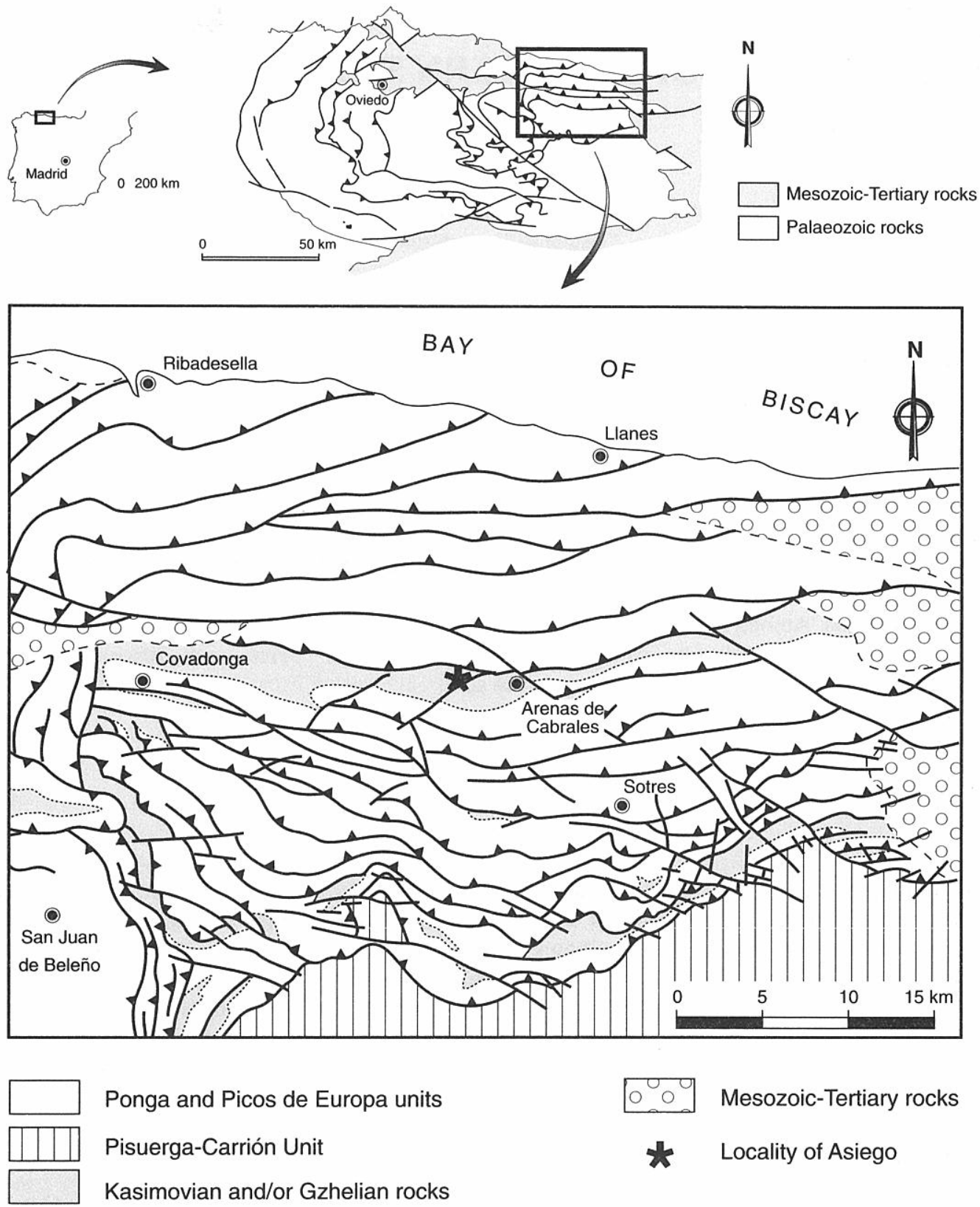

Ponga and Picos de Europa units

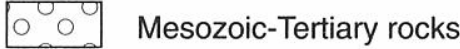

Pisuerga-Carrión Unit

Kasimovian and/or Gzhelian rocks

Figure 1. Situation of the locality of Asiego in the Cantabrian Zone.

the west, being represented by only a few meters of limestones near Arenas de Cabrales, in the GamonedoCabrales area.

The fusulinaceans from the upper part of the Puentellés Formation allowed van Ginkel (1971) to establish a Late Kasimovian age (Dorogomilovsky) for those beds, and this was confirmed in subsequent studies by Truyols et al. (1984) and Villa (1995). The terrestrial deposits at the base of the Puentellés Formation yielded some floral remains of Stephanian B age (Martínez García and Wagner, 1971, Wagner and Martínez García, 1998).

The Cavandi Formation rests on the Puentellès Formation with apparent conformity, and consists of 240 $\mathrm{m}$ of alternating mudstones, calcareous sandstones, thin beds of fine-grained carbonate debris-flows, and turbiditic sandstones with alternating mudstones at the top. Its age can only be established indirectly from data obtained in the underlying Puentellés Formation.

The fusulinacean fauna from the Puentellés Formation studied by van Ginkel (1971) corresponds to two schwagerinids species of the genera Montiparus and Ferganites, which were initially described as Triticites (Montiparus) fischeri van Ginkel sp. nov., and Triticites ohioensis benshi van Ginkel subsp. nov. However, a later revision by Villa (1995) showed that Triticites ohioensis benshi could in fact be assigned to Ferganites ferganensis (Miklukho-Maklay). Intensive sampling of the Puentellés Formation in the last few years reveals that both Montiparus fischeri and Ferganites ferganensis are widespread in these uppermost Carboniferous strata, although, as was already pointed out by van Ginkel, Montiparus fischeri occurs in slightly older strata than Ferganites ferganensis. 

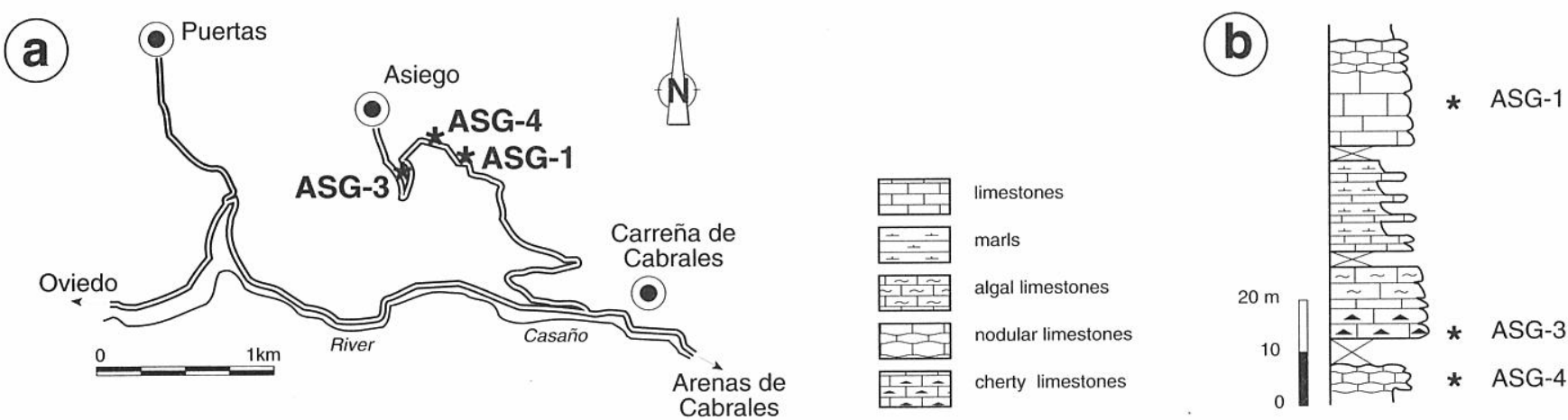

Figure 2. a) Scheme showing the situation of the three stations sampled along the road from Carreña de Cabrales to Asiego. b) Stratigraphic position of the three fossiliferous beds.

\section{THE CARBONIFEROUS STRATA OF ASIEGO}

The locality of Asiego is situated near the village of Carreña de Cabrales, in the Gamonedo-Cabrales area. Some isolated rocks crop out along the road from Carreña to Asiego (Fig. 2), on the southern slope of the Casaño River valley. These strata dip southwards, consist mainly of marly limestones and limestones (sometimes with silicified fauna), and are overlain by sandstones and shales. The relation of these strata with the Puentellés Formation, which is exposed on the northern slope of the Casaño valley, and clearly dipping northwards, remains unclear.

Several samples collected in three limestone beds (ASG-1, ASG-3, and ASG-4; Fig. 2b) have provided various fusulinacean species. Listed from bottom to top, these faunas are:

\begin{tabular}{|c|c|}
\hline \multirow[t]{3}{*}{ ASG-4 } & Quasifusulina longissima (Möller) \\
\hline & Rauserites sp. \\
\hline & Ferganites sp. \\
\hline ASG-3 & Quasifusulina longissima (Möller) \\
\hline & Jigulites sp. \\
\hline$A S G_{-1}$ & $\begin{array}{l}\text { Triticites aff. acutus Dunbar and Cond } \\
\text { Rauserites cf. erraticus (Rozovskaya) }\end{array}$ \\
\hline
\end{tabular}

This fusulinacean fauna, whose characteristics and stratigraphic significance will be discussed below, suggests a probable early Gzhelian age for the Asiego beds. This is younger than would be expected for the Puentellés Formation. However, it seems only reasonable to assume that the limestones situated in the surroundings of Asiego represent the top of Puentellés and that the overlying sandstones and shales correspond to the base of the Cavandi Formation.

The fusulinaceans from the Asiego beds are comparable to the uppermost Carboniferous fusulinaceans of the Russian Platform, Urals and Middle Asia, as described by Rauser-Chernoussova (1938), Rozovskaya (1950, 1952, 1958, 1975), Bensh (1972), Chuvashov et al. (1986), Isakova (1986), Konovalova (1991), Remizova (1995), among others. Because previously the Puentellés Formation, including the upper part, has always been dated as Kasimovian, especial attention will need to be paid now to the characteristic fusulinacean assemblages that allow dating it as either Kasimovian or Gzhelian.

\section{FUSULINACEAN BIOZONES OF THE UPPER KASIMOVIAN AND LOWER GZHELIAN DEPOSITS IN RUSSIA}

The Kasimovian and Gzhelian stages were established in strata of the Russian Platform, where they have been subdivided into several smaller units, called "horizons" according to Russian terminology. These horizons, represented in Fig. 3, are considered chronostratigraphic units, although bearing an informal status. Out of the four Kasimovian horizons (Krevyakinsky, Khamovnichesky, Dorogomilovsky and Yauzsky), the Yauzsky horizon is sometimes difficult to discern. On account of that, some authors (e. g. Rotai, 1979) include it as part of the Dorogomilovsky, which leaves the Kasimovian with three horizons only.

Similarly, the two lower horizons of the Gzhelian (the Retchisky, formerly Russavskinsky, and the Amerevsky) are sometimes taken as two separate horizons (e. g. Rauser-Chernoussova et al., 1979) whilst some other times they are considered as just one (e. g. Einor, 1996). The Amerevsky is followed by the Pavlo-Posadsky and the Noginsky horizons.

Within these two stages, several fusulinacean biozones have been established, characterizing the horizons mentioned above (Fig. 3). However, this paper will focus just on the uppermost biozone of the Kasimovian and the two lower biozones of the Gzhelian, since this is the interval within which the fusulinaceans from Asiego fit. The fusulinaceans from older or younger levels have rather different features and, therefore, have been excluded from this discussion.

The highest Kasimovian fusulinacean biozone is the $\mathrm{C}_{3} \mathrm{~B}$ Zone, or the Triticites quasiarcticus-Triticites acutus Zone (formerly Triticites arcticus-Triticites acutus Zone), which is roughly equivalent to the Dorogomilovsky and Yauzsky horizons together. [Triticites quasiarcticus is the new name given by Solovieva (1987) for Triticites arcticus (Schellwien, 1908) identified by RauserChernoussova, 1938]. The most relevant feature of this biozone is the abundance of typical Triticites, represented 
by diverse species such as Triticites acutus Dunbar and Condra and Triticites irregularis (Schellwien and Staff). Advanced species of Montiparus, like M. subcrassulus Rozovskaya, are also common. Carboniferous strata of this biozone in Middle Asia commonly show species belonging to the genus Ferganites too. Some rare specimens of this genus occasionally occur in the underlying biozone.

The Rauserites stuckenbergi Zone $\left(\mathrm{C}_{3} \mathrm{C}\right)$ characterizes the lower Gzhelian, comprising the Russavskinsky plus the Amerevsky horizons. Here the most relevant feature is the abundance of Rauserites. Rauserites stuckenbergi (Rauser-Chernoussova), Rauserites paraarcticus (RauserChernoussova), and Rauserites rossicus (Schellwien) are some of the species mentioned by Rauser-Chernoussova et al., 1979, in this interval. However, the separation of Triticites and Rauserites may sometimes be problematic, quasiarcticus-Triticites acutus Zone are often assigned to the genus Rauserites [e. g. Rauserites variabilis (Rozovskaya, 1950), and Rauserites bashkiricus (Rozovskaya, 1950)]. Therefore, the first occurrence of Rauserites does not seem a reliable criterium to mark the lowermost Gzhelian.

Above Rauserites stuckenbergi Zone, the Jigulites jigulensis Zone $\left(\mathrm{C}_{3} \mathrm{D}\right)$ represents an interval coinciding with the Pavlo-Posadsky horizon (Fig. 2). Some Jigulites like J. jigulensis (Rauser-Chernoussova), J. volgensis (Rauser-Chernoussova) and J. dagmarae (Rozovskaya) are often assemblage components of this biozone, although these species may be rare within the underlying Rauserites stuckenbergi Zone (see the stratigraphic ranges showed in Grigorieva et al., 1996). In any case, it seems clear that the first occurrence of Jigulites is undoubtedly in Gzhelian strata.

According to all this, Triticites, Rauserites and Jigulites respectively appear as the most significant genera of the mentioned fusulinacean biozones $\left(\mathrm{C}_{3} \mathrm{~B}, \mathrm{C}_{3} \mathrm{C}\right.$ and $\mathrm{C}_{3} \mathrm{D}$ ). The stratigraphic significance of these genera had already been pointed out by Rozovskaya $(1948,1950)$. At first, Rauserites and Jigulites were considered subgenera of Triticites, which indicates how closely connected are all these taxa. Montiparus would be the common ancestor leading to Triticites, in one branch, and to RauseritesJigulites, in the other branch. Davydov (1988) considered that both branches separated earlier and that Protriticites would have been the common ancestor. A revision of this phylogeny placed the common ancestor (Fusulinella) even earlier (Davydov, 1990).

The three genera, Triticites, Rauserites, and Jigulites, keep close morphological similarities. After Rozovskaya (1948), Davydov (1990), and the recently published and some doubtful species occurring at the Triticites

reference book by Rauser-Chernoussova et al. (1996), it is accepted that Rauserites differs from Triticites in that the former has more intensive septal folding. According to Rozovskaya (1948), the septal folding in Rauserites tends to be more regular than in Triticites. However, Bensh (in Rauser-Chernoussova et al., 1996) emended the original description of Rauserites and stated that this genus has irregular septal folding. Jigulites, on the other hand, differs from the other two genera in its thicker wall, stronger and higher septal folding, and in having chomata developed only in the inner volutions and either absent or replaced by pseudochomata in the outer ones.

\section{THE FUSULINACEANS FROM ASIEGO}

\section{SYSTEMATICS}

The fusulinaceans of Asiego constitute a noteworthy fauna as they include the most advanced fusulinacean fauna so far recorded in the Carboniferous of the Cantabrian Mountains (and therefore in the Carboniferous of Western Europe). These species, belonging to typical Triticites, large Quasifusulina, Rauserites, Ferganites, and Jigulites are described briefly below.

Measurements of the following characters are determined: L: maximum length (in $\mathrm{mm}$ ); $\mathrm{D}$ : maximum diameter (in $\mathrm{mm}$ ); L/D: length to diameter ratio; no: number of whorls; d: outside diameter of the proloculus (in $\mu$ ); w.th.: wall thickness (penultimate whorl/ultimate whorl) in $\mu$; $\mathrm{D}_{4}$ : diameter of the fourth whorl (in $\mathrm{mm}$ ); $\mathrm{Rv}$ : radius vector (in $\mathrm{mm}$ ); Fr: form ratio (half length to radius vector ratio).

All material deposited in the Geological Department of the University of Oviedo, Spain.

Family Schwagerinidae Dunbar and Henbest, 1930 Genus Triticites Girty, 1904

Type-species: Miliolites secalicus Say, 1823.

Triticites aff. acutus Dunbar and Condra, 1927

Pl. I, figs. 1-9; Pl. II. figs. 1, 6

$\begin{array}{lccccccccc}\text { Measurements } & & & & & & & & \\ \text { Sample No. } & \text { L } & \text { D } & \text { L/D } & \text { no } & \text { d } & \text { w. th. } & \text { D }_{4} & \text { Rv } & \text { Fr } \\ \text { ASG-1/1 } & 7.76 & 2.06 & 3.77 & 5 & 265 & 59 / 83 & 1.61 & 1.05 & 3.70 \\ \text { ASG-1/2 } & 6.52 & 2.02 & 3.22 & 5.5 & - & 69 / 73 & 1.24 & 1.09 & 3.00 \\ \text { ASG-1/4 } & 7.35 & 1.84 & 4.00 & 6 & - & 59 / 88 & 0.86 & 0.98 & 3.77 \\ \text { ASG-1/5 } & 5.92 & 1.84 & 3.22 & 5 & 196 & 54 / 69 & 1.28 & 0.98 & 3.04 \\ \text { ASG-1/6 } & 5.44 & 1.61 & 3.37 & 5 & 196 & 54 / 69 & 1.16 & 0.83 & 3.29 \\ \text { ASG-1A/1 } & 6.53 & 2.14 & 3.05 & 5 & 225 & 59 / 59 & 1.54 & 1.16 & 2.81 \\ \text { ASG-1A/2 } & 8.06 & 2.18 & 3.71 & 6 & - & 64 / 69 & 1.13 & 1.16 & 3.47\end{array}$

\section{Measurements}

Plate I. Triticites aff. acutus Dunbar and Condra. All x 15.

1 Specimen ASG-1A/3.

2 Specimen ASG-1/6.

3 Specimen ASG-1E/3.

4 Specimen ASG-1/5.

5 Specimen ASG-1/2.
6 Specimen ASG-1/1.

7 Specimen ASG-1/4.

8 Specimen ASG-1A/2.

9 Specimen ASG-1A/4. 
Plate I

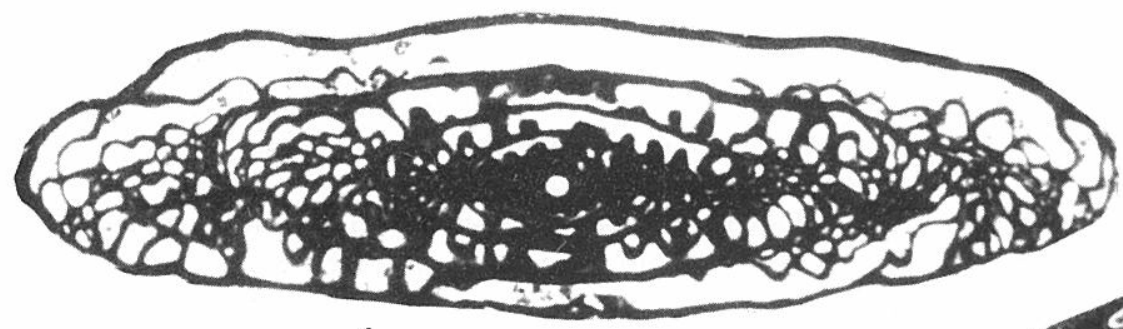

1
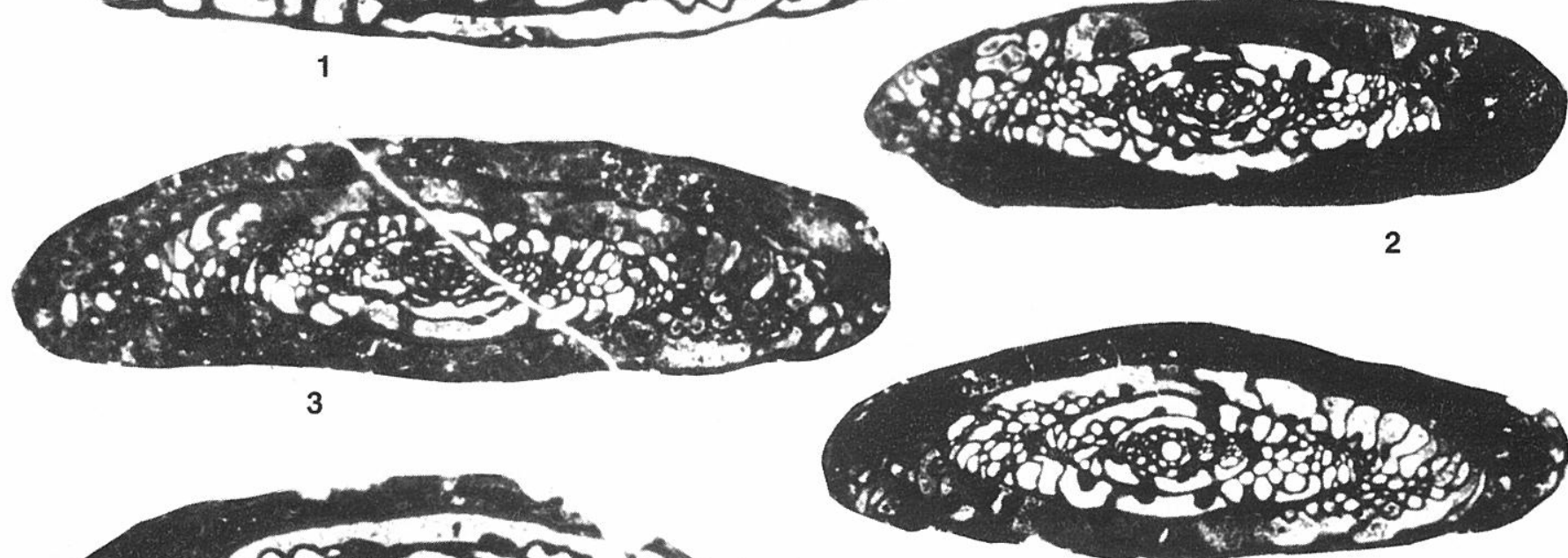

4

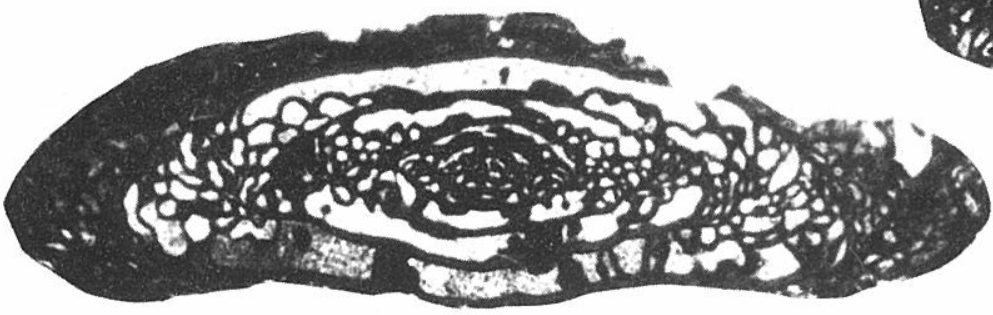

5
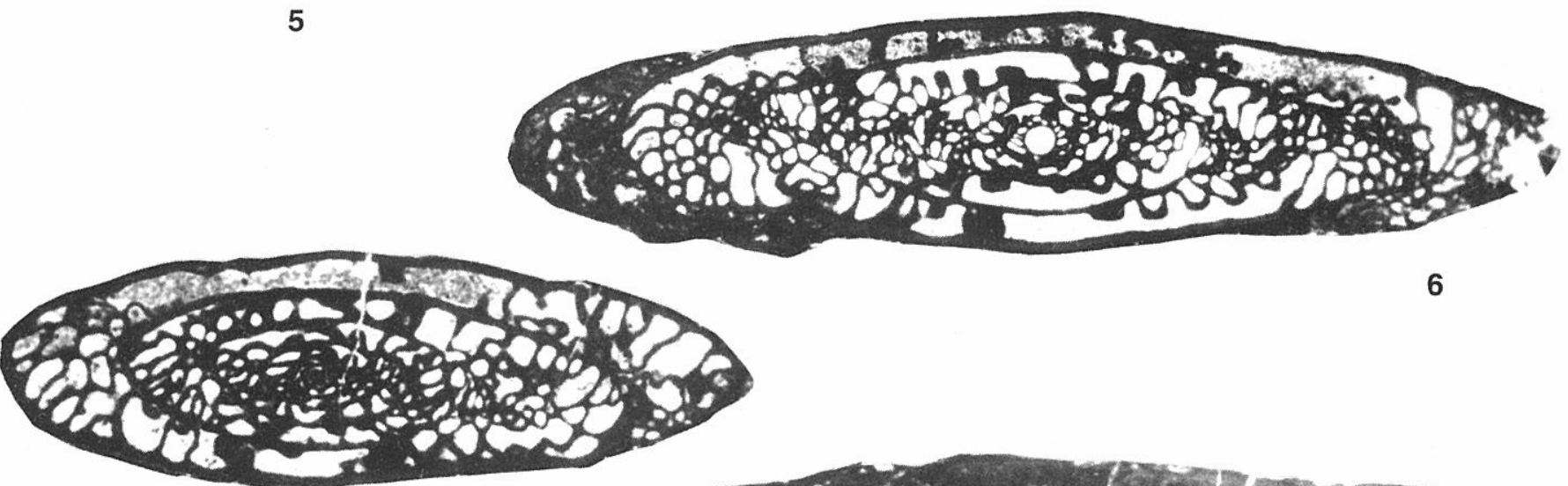

6
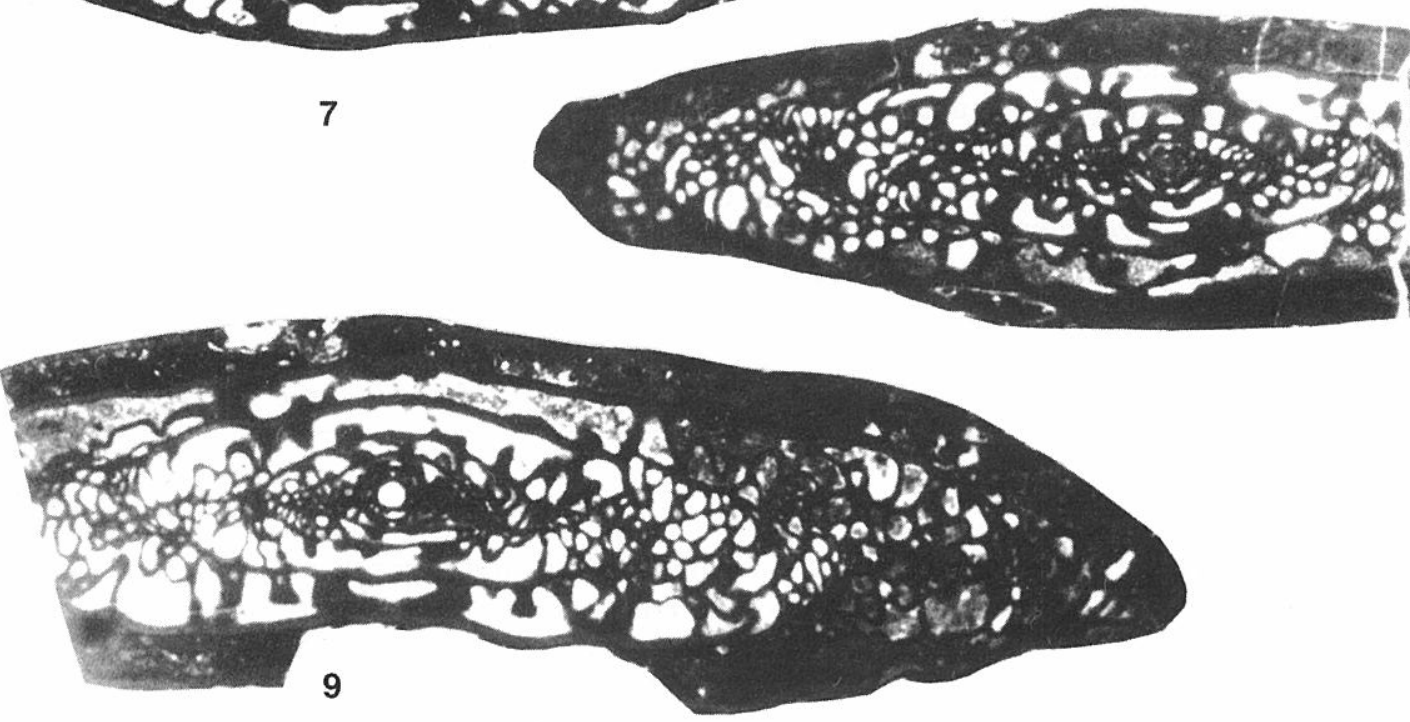


$\begin{array}{lrllllllll}\text { ASG-1A/3 } & 7.09 & 1.97 & 3.60 & 5.5 & 206 & 66 / 66 & 1.43 & 1.11 & 3.20 \\ \text { ASG-1A/4 } & 10.20 & 2.48 & 4.12 & 6 & 240 & 83 / 88 & 1.28 & 1.28 & 4.00 \\ \text { ASG-1E/1 } & 7.16 & 2.21 & 3.24 & 5.5 & - & 69 / 73 & 1.35 & 1.16 & 3.08 \\ \text { ASG-1E/2 } & 4.88 & 1.69 & 2.89 & 4.5 & - & 54 / 64 & 1.50 & 0.90 & 2.71 \\ \text { ASG-1E/3 } & 6.71 & 1.91 & 3.51 & 5.5 & - & 69 /- & 1.13 & 1.05 & 3.20 \\ \text { ASG-1E/4 } & 6.60 & 1.73 & 3.82 & 5.0 & 206 & 49 / 83 & 1.13 & 0.94 & 3.52 \\ \text { ASG-1E/5 } & 4.58 & 1.43 & 3.21 & 5 & 196 & 49 / 54 & 1.03 & 0.75 & 3.05 \\ & & & & & & & & & \\ \text { average } & 6.77 & 1.94 & 3.48 & 5.3 & 216 & 61 / 72 & 1.26 & 1.03 & 3.27\end{array}$

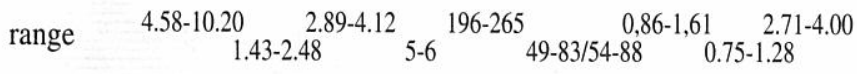

\section{Remarks}

This species has an elongate-fusiform shape, pointed poles, and weak septal folding along the central part of the shell. The present specimens from Asiego are obviously quite close to the specimens which Russian authors usually assign to Triticites acutus Dunbar and Condra, 1927 (see Rauser-Chernoussova, 1938; Rozovskaya, 1958; Grozdilova et al., 1975; Alksne, 1979; Konovalova, 1991). Still, there are several features which distinguish our Triticites aff. acutus from the American species described by Dunbar and Condra (1927): 1) the asymmetrically shaped and more weakly developed chomata; 2) the much wider aperture of the tunnel; 3) the larger maximum and average values of the diameter of the proloculum; 4) the smaller number of volutions. The same differences are apparent between the American type material and the Russian forms assigned to $T$. acutus as is well shown for the specimens of $T$. acutus described by Rozovskaya (1958) and by Konovalova (1991).

Very close to the Asiego forms is Triticites subacutus Mikhailova. This form, described from the northern Urals (Mikhailova, 1967), only differs from $T$. aff. acutus from the Cantabrian Mountains in having better developed chomata and perhaps a, on average, larger proloculus. Apparently, the same differences hold for Triticites subacutus Mikhailova and most of the specimens assigned by Russian authors to T. acutus.

On the other hand, our material, apart from specimens of Triticites acutus in the wider (Russian) sense, also contains specimens which, in Russian papers, are assigned to other species. For instance, our specimens figured in Pl. I, figs. 2 and 4, may be compared with Triticites tabinicus Alksne in terms of size, number of whorls, and L/D ratio. Our specimens in Pl. I, figs. 3, 7, and 8 resemble $T$. orysiformis Newell, as identified by Alksne (1979), on account of the small size of the proloculum and the type of septal folding. The specimen in Pl. I, fig. 9 is similar to Rauserites rossicus (Schellwien), especially with respect to the great L/D ratio and the large size of the shell (it should be noted, however, that in $R$. rossicus septal folding is much more intense).

Despite the similarity to various other species, the specimens from Asiego discussed here are considered to be conspecific and part of an assemblage in which the shells of its individuals vary notably in size and elongation. The assumed conspecifity is supported by their close resemblance with regard to other features, notably the septal folding, the type of the chomata, and the shape of the initial volution.

The species, which occurs in the Carboniferous of the former USSR, and which has been usually assigned to Triticites acutus Dunbar and Condra, is usually considered in Russian papers to be typical of the upper Kasimovian (Dorogomilovsky and Yauzsky). However, according to Davydov (pers. comm.), it has also been found in the lower Gzhelian.

\section{Genus Rauserites Rozovskaya, 1948}

Type-species: Triticites stuckenbergi Rauser-Chernoussova, 1938.

\section{Rauserites cf. erraticus (Rozovskaya, 1952)} Pl. II, fig. 3

\section{Measurements}

Sample No. L D L/D no d w. th. $\mathbf{D}_{\mathbf{4}} \mathbf{R v} \quad \mathbf{F r}$ $\begin{array}{llllllllll}\text { ASG-1/9 } & 5.93 & 2.25 & 2.63 & 5.5 & 206 & 93 / 88 & 1.34 & 1.20 & 2.47\end{array}$

\section{Remarks}

This species has a relatively short and inflated shell, with rounded poles, rather intense septal folding, and a thick wall $(93 \mu$ in the penultimate whorl and $88 \mu$ in the ultimate one). Specimen ASG-1(9) is similar to various schwagerinid species usually assigned to the genus Rauserites. Our specimen is particularly close to Rauserites erraticus (Rozovskaya) in the size of the shell, the expansion of the spiral (very tight in early whorls, becoming rapidly wider in subsequent whorls), and the diameter of the fourth whorl.

Rauserites erraticus was described by the $\mathrm{C}_{3}{ }^{1-\mathrm{c}}$ Zone of the Carboniferous of the South Urals. According to Rozovskaya (1948), the species of Rauserites having the characteristic features mentioned above typically occur during a short time interval restricted to the Zone $\mathrm{C}_{3}{ }^{1-\mathrm{c}}$ (= $\mathrm{C}_{3} \mathrm{C}$ of Fig. 3), which is equivalent to the lower Gzhelian. In some Russian papers, however, the genus is shown to

\section{Plate II}

1 Microstructure of the wall in Triticites aff. acutus Dunbar and Condra. Specimen ASG-1A/3. x 100.

2 Microstructure of the wall in Quasifusulina longissima (Möller). Specimen ASG-3/4. x 100.

3 Rauserites cf. erraticus (Rozovskaya). Specimen ASG-1/9. x 15.

5 Jigulites sp. Specimen ASG-3B/3. x 15.

6 Triticites aff. acutus Dunbar and Condra. Specimen ASG-1A/1. x 15.

7 Quasifusulina longissima (Möller). Specimen ASG3/4. x 15.

$8 \quad$ Ferganites sp. Specimen ASG-4/2. x 15.

4 Rauserites sp. Specimen ASG-4/3. x 15. 
Plate II

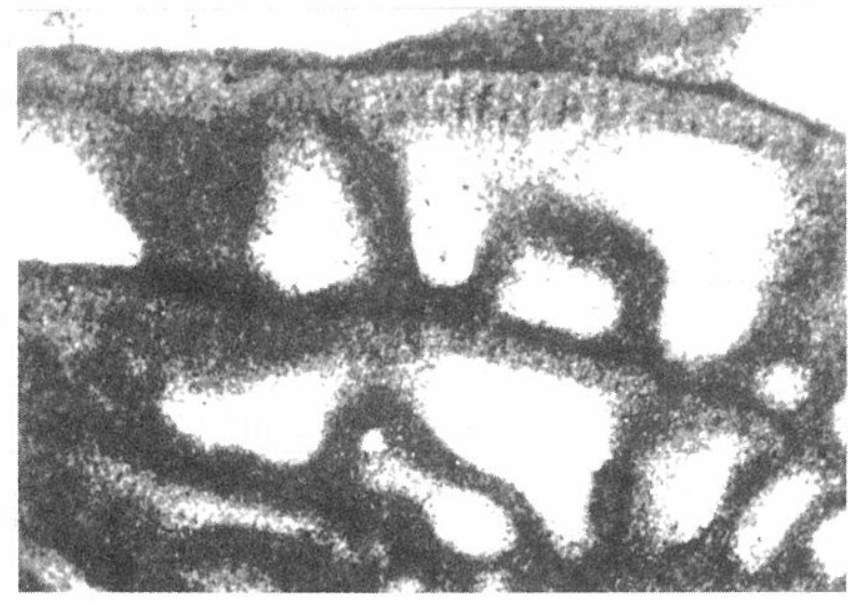

1

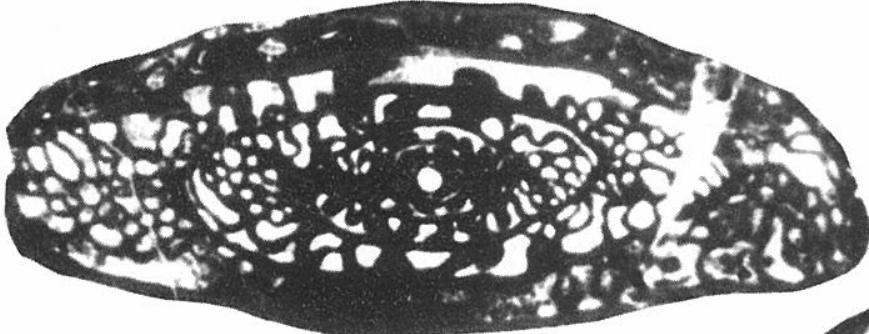

3

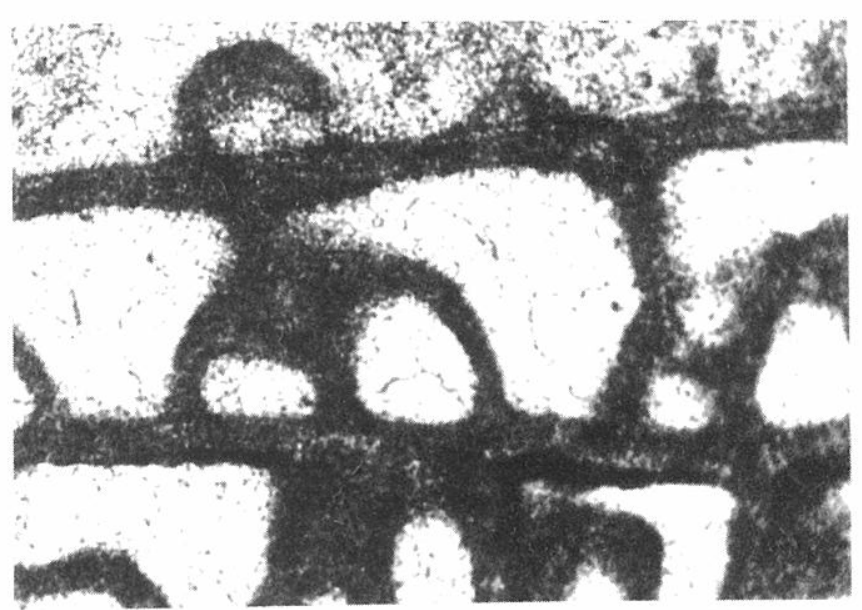

2
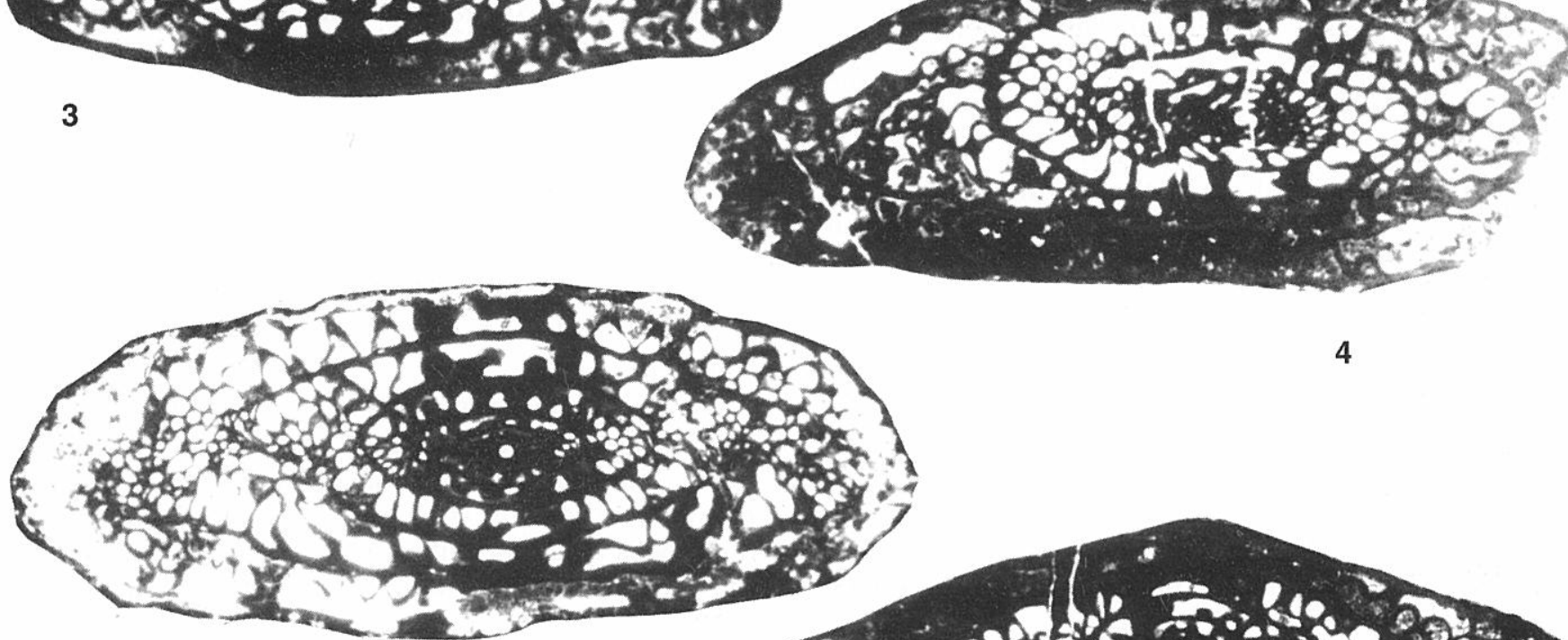

5
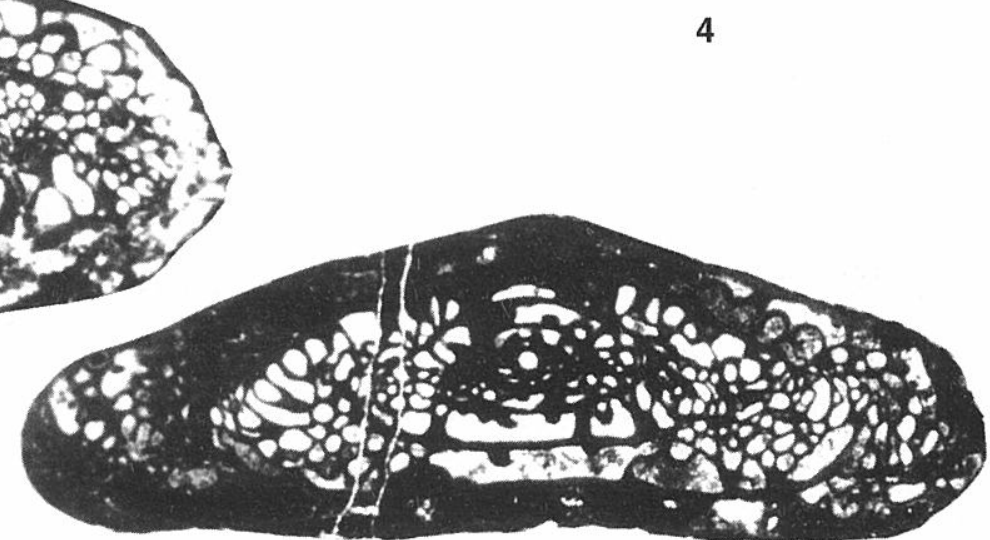

6
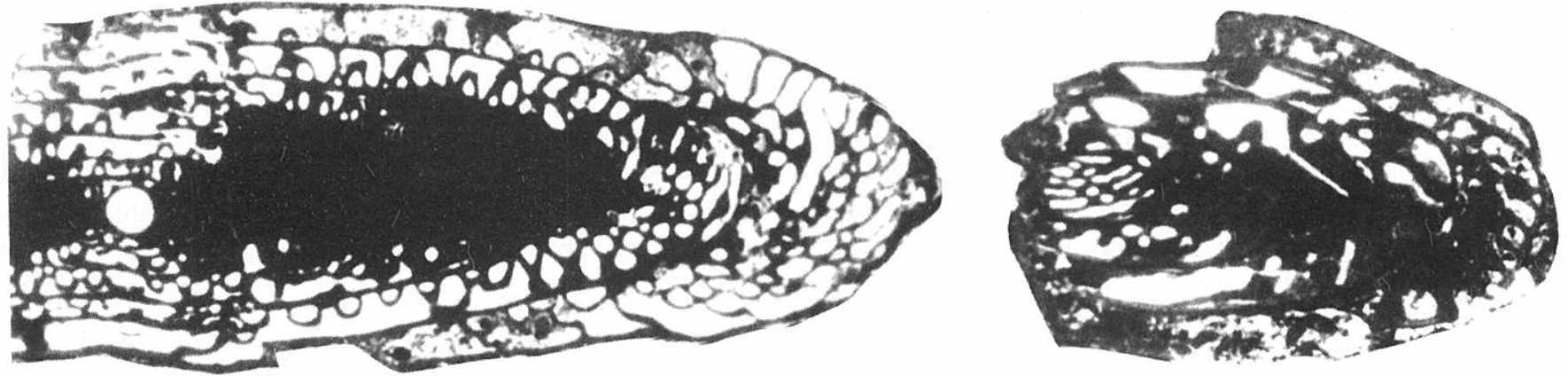

7 


\begin{tabular}{|c|c|c|c|}
\hline & \multicolumn{2}{|c|}{ Foraminif eral zones } & \multirow{2}{*}{$\frac{\text { Horizons }}{\text { Noginsky }}$} \\
\hline \multirow{3}{*}{$\begin{array}{l}\mathbf{Z} \\
\mathbf{J} \\
\text { 至 } \\
\mathbf{J} \\
\mathbf{N}\end{array}$} & $\mathrm{C}_{3} \mathrm{E}$ & Daixina sokensis Zone & \\
\hline & $\mathrm{C}_{3} \mathrm{D}$ & Jigulites jigulensis Zone & Pavlov-Posadsky \\
\hline & $\mathrm{C}_{3} \mathrm{C}$ & Rauserites stuckenbergi Zone & $\begin{array}{l}\text { Amerevsky } \\
\text { Retchisky }\end{array}$ \\
\hline \multirow{3}{*}{ 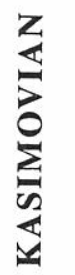 } & $\mathbf{C}_{3} \mathbf{B}$ & Triticites quasiarcticus-Triticites acutus Zone & $\begin{array}{c}\text { Yauzsky } \\
\text { Dorogomilovsky }\end{array}$ \\
\hline & $\mathrm{C}_{3} \mathrm{~A}_{2}$ & Montiparus montiparus Zone & Khamovnichesky \\
\hline & $\mathrm{C}_{3} \mathrm{~A}_{1}$ & $\begin{array}{l}\text { Protriticites pseudomontiparus- } \\
\text { Obsoletes obsoletus Zone }\end{array}$ & Krevyakinsky \\
\hline
\end{tabular}

Figure 3. Stratigraphic units (foraminiferal zones and horizons) of the Kasimovian and Gzhelian stages in their stratotype area (Russian Platform). The shaded interval indicates the most probable correlation level of the Asiego beds.

appear already in the Kasimovian (e. g. Grigorieva et al., 1996). It is obvious nevertheless, that during the (lower) Gzhelian the genus was much better represented and showed a great geographic extension as well.

The only earlier find of a species of Rauserites in the Cantabrian Mountains was reported by Villa (1995) as Triticites (Rauserites?) sp. from a locality close to the village of Inguanzo (also situated in the GamonedoCabrales area). Rauserites cf. erraticus has a thicker wall and stronger septal folding than the species from Inguanzo, so we consider the latter to be different from the present Asiego form.

\section{Rauserites sp. \\ Pl. II, fig. 4}

\section{Measurements} $\begin{array}{llllllllll}\text { Sample No. } & \mathbf{L} & \mathbf{D} & \mathbf{L} / \mathbf{D} & \text { no } & \mathbf{d} & \text { w. th. } \mathbf{D}_{\mathbf{4}} & \mathbf{R v} & \mathbf{F r} \\ \text { ASG-4/3 } & 8.25 & 2.48 & 3.33 & 6 & 196 & 59 / 59 & 1.20 & 1.24 & 3.33\end{array}$

\section{Remarks}

Our samples yielded one specimen which is singular in being conspicuously different from the other specimens found at the Asiego locality. Its septal folding is too irregular and intense for a Triticites and too weak in the central region to be considered a Jigulites. We believe, therefore, that this specimen belongs to the genus Rauserites although it is not conspecific with the species of locality ASG-1 (Rauserites cf. erraticus) from which it differs by its larger-sized shell, more slender shape, weaker chomata, and thinner wall. Because only a single section of this specimen is available, showing neither a precise axial orientation nor a good preservation, a specific determination has not been carried out.

\section{Genus Jigulites Rozovskaya, 1948}

Type-species: Triticites jigulensis Rauser-Chernoussova, 1938.

\section{Jigulites sp. \\ Pl. II, fig. 5}

\section{Measurements}

Sample No. L D $\quad$ L/D no d $\quad$ w. th. $\mathbf{D}_{\mathbf{4}} \quad \mathbf{R v} \quad \mathbf{F r}$

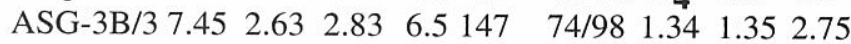

\section{Remarks}

Some features of the single specimen present (ASG$3 \mathrm{~B} / 3$ ) show rather convincingly that it is assignable to the genus Jigulites. These characteristics are: a rapidly but regularly expanding spire, intensive septal folding with high loops along the entire shell, presence of chomata in the inner two and one-half whorls (developing into pseudochomata in the outer whorls), and a relatively thick spirotheca.

This is the first specimen of genus Jigulites recorded in the Carboniferous of the Cantabrian Mountains. In view of the fact that in the former USSR this genus does not appear until the Gzhelian, the present specimen has stratigraphic significance, since it strongly points to the possibility that fusulinaceans of such young age occur in the Cantabrian Mountains as well. This possibility is supported by the presence of Rauserites cf. erraticus (Rozovskaya), found at the same section in a level some $40 \mathrm{~m}$ above the present one.

Among the species of Jigulites described in previous papers, there are three which bear some resemblance with our form. These species, Jigulites formosus (Rosovs-

Plate III. Quasifusulina longissima (Möller). All for x 15.

1 Specimen ASG-3/6.

2 Specimen ASG-3/5.

3 Specimen ASG-3/2. 

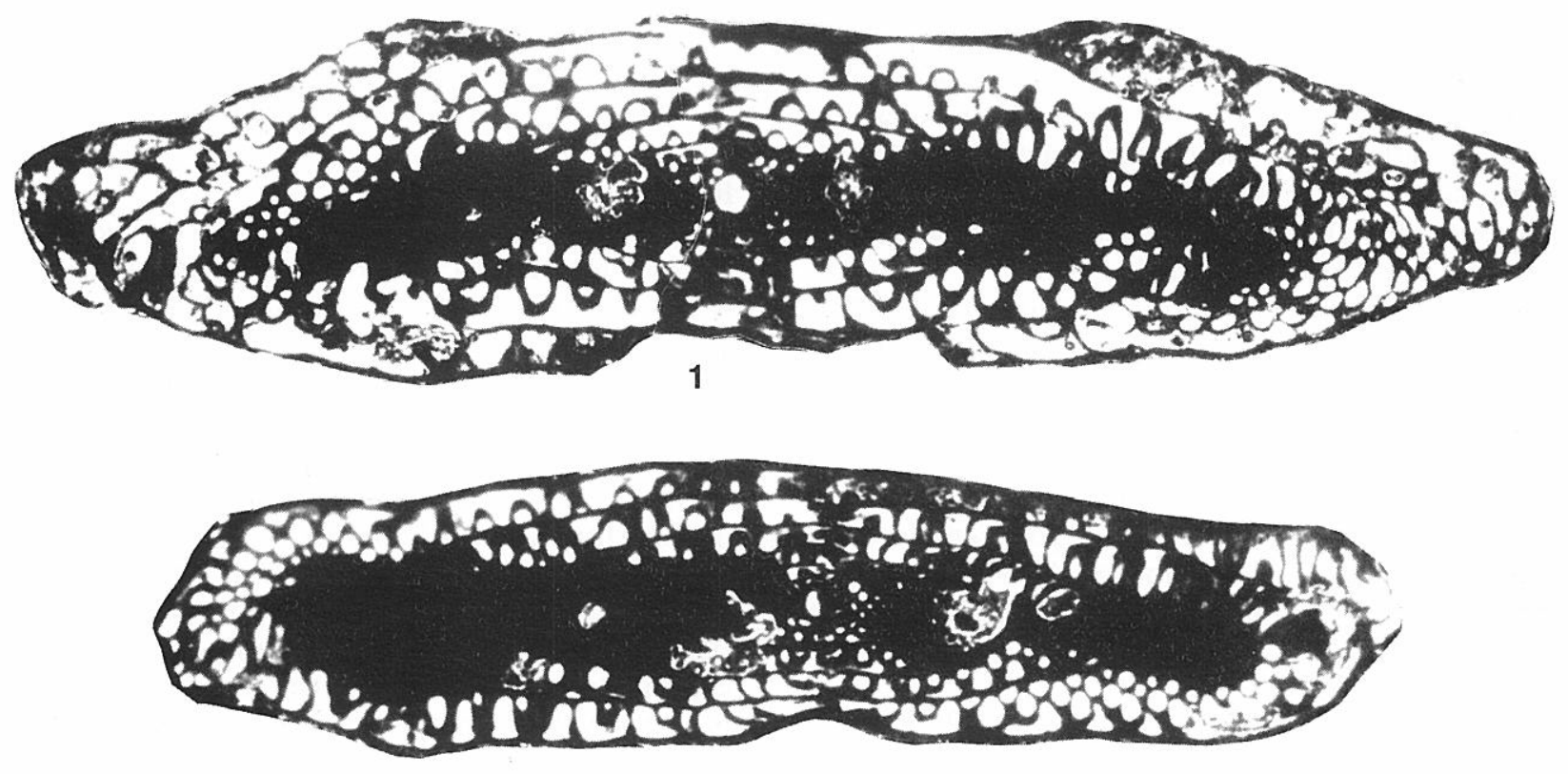

2

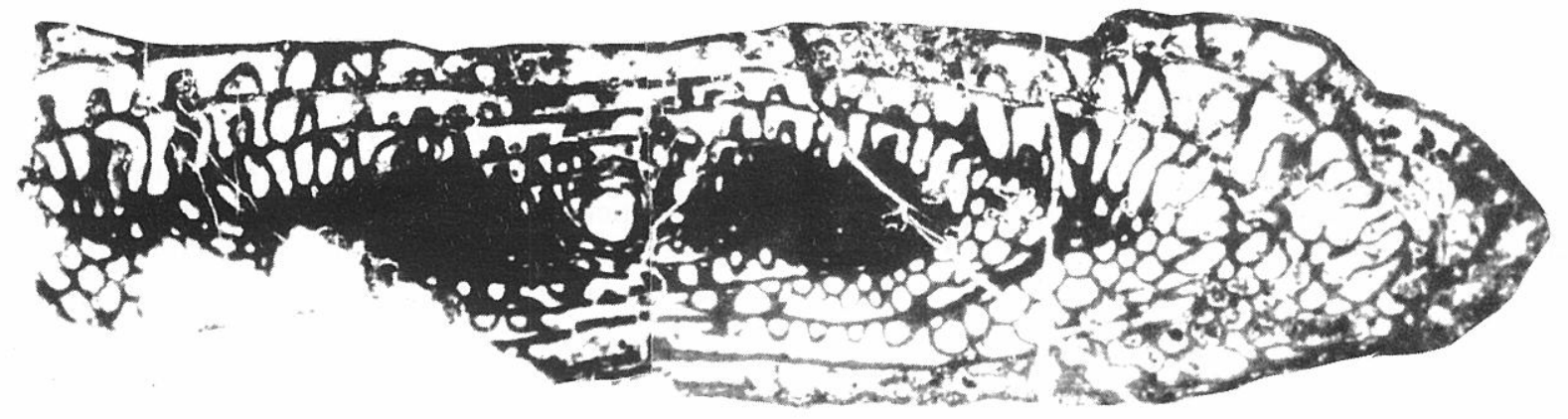

3

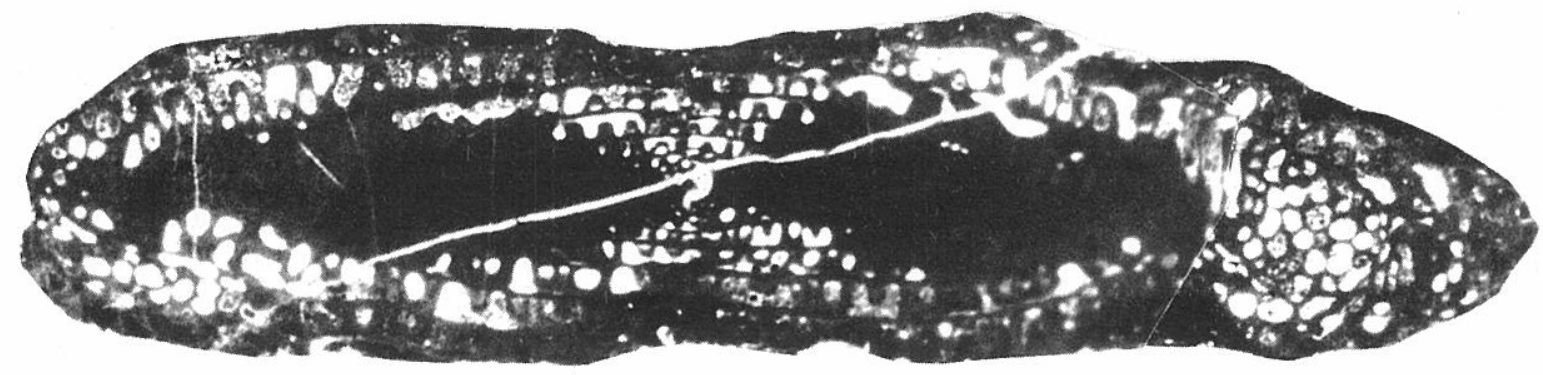

4

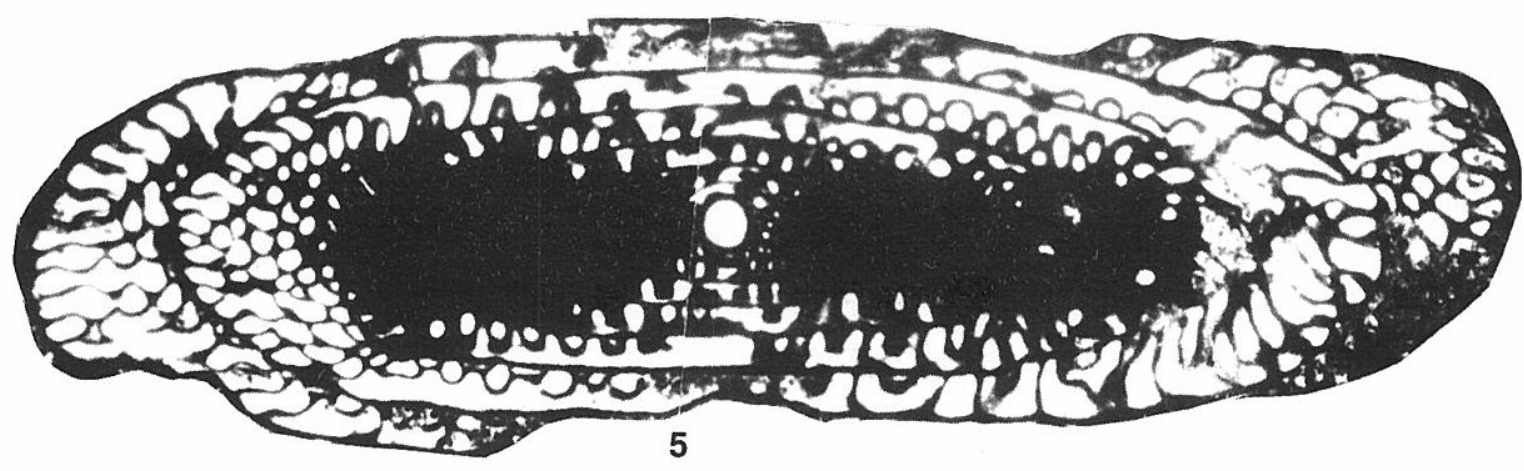


kaya), Jigulites jigulensis (Rauser-Chernoussova), and Jigulites volgensis (Rauser-Chernoussova), are quite close to our specimen in size, L/D ratio, and expansion of the volutions. Still, Jigulites formosus has larger proloculus and probably more sharply pointed poles, $J$. volgensis seems to have weaker septal folding, whereas $J$. jigulensis, besides having more sharply pointed poles, also presents a less elongated shell.

The closest forms, however, seem to be two specimens from the lower Gzhelian of the South Urals studied by Davydov and figured in Chuvashov, et al. (1986; Pl. 11). These specimens have been identified by Davydov as Jigulites formosus formosus Rozovskaya (op. cit. Pl. 11, fig. 10) and Jigulites aff. longus Rozovskaya (Pl. 11, fig. 9). Jigulites sp. from Asiego resembles both specimens in the general shape of the shell and the expansion of the spire, but the septal folding makes it closer to the former one.

Genus Ferganites Miklukho-Maklay, 1959

Type-species: Triticites ferganensis Miklukho-Maklay, 1950.

Ferganites sp.

Pl. II, fig. 8

\section{Measurements}

Sample No. L $\quad$ D $\quad$ L/D no $\quad$ d w. th. $\mathbf{D}_{\mathbf{4}} \quad \mathbf{R v} \quad \mathbf{F r}$ $\begin{array}{llllllllll}\text { ASG-4/2 } & 7.5 & 2.7 & 2.78 & 5.5 ? & - & 64 / 74 & - & 1.43 & 2.62\end{array}$

\section{Remarks}

These measurements, approximations only, refer to a single para-axial and broken specimen. Nevertheless, some typical features of Ferganites, like the subcylindrical form, the septal folding confined to the polar region, and the presence of axial fillings, can still be noted. In comparison with other species of Ferganites the L/D ratio is conspicuously low. However, similar low values have been measured in other, still unpublished, specimens of this genus found to the east of Asiego (Panes area).

Family Fusulinidae Möller, 1878

Genus Quasifusulina Chen, 1934

Type-species: Fusulina longissima Möller, 1878.

Quasifusulina longissima (Möller, 1878)

Pl. II, figs. 2, 7; Pl. III, figs. 1-5

\section{Measurements}

Sample No. L D L/D no d w. th. $\mathbf{D}_{\mathbf{4}}$ Rv $\mathbf{F r}$ $\begin{array}{llllllllll}\text { ASG-3/1 } & 10.27 & 2.85 & 3.60 & 6.5 & 412 & 39 / 44 & 1.54 & 1.54 & 3.34\end{array}$ $\begin{array}{llllllllll}\text { ASG-3/2 } & 12.22 & 2.55 & 4.79 & 6 & 421 & 59 / 49 & 1.46 & 1.35 & 4.52\end{array}$ $\begin{array}{llllllllll}\text { ASG-3/3 } & 10.24 & 2.85 & 3.59 & 6.5 & 402 & 44 / 44 & 1.58 & 1.58 & 3.25\end{array}$ $\begin{array}{llllllllll}\text { ASG-3/4 } & 12.30 & 2.63 & 4.69 & 5.5 & 412 & 34 / 49 & 1.73 & 1.46 & 4.21\end{array}$ $\begin{array}{llllllllll}\text { ASG-3/5 } & 8.93 & 1.91 & 4.67 & 5.5 & 304 & 34 / 34 & 1.28 & 0.98 & 4.58\end{array}$

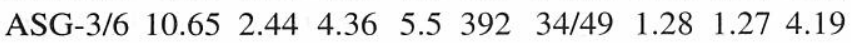

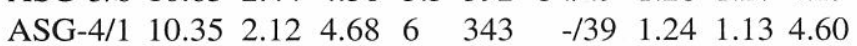

$\begin{array}{llllllllll}\text { average } & 10.42 & 2.48 & 4.34 & 6 & 384 & 41 / 44 & 1.44 & 1.33 & 4.10\end{array}$

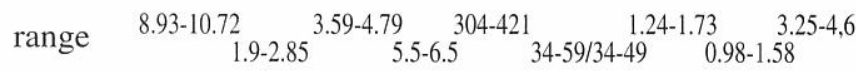

\section{Remarks}

The present specimens conform to Quasifusulina longissima (Möller) with respect to the large size of the shell, the diameter of the proloculum, and the rather regular folding of the septa. This similarity notwithstanding, in the Asiego specimens, the shape of the shell shows a higher degree of variability than previously described species of this genus.

In this respect, it should be noted that but for one of the specimens (Pl. III, fig. 1), which shows the typical Quasifusulina longissima rounded poles, the majority present somewhat extended and pointed poles (e. g., Pl. III, figs. 3, 5). However, considering the great similarity shown by many other characters, it does not seem likely that the differences of polar ends should indicate the presence of more than one species but, rather, the intraspecific variability of this feature. A recent paper by Watanabe (1997), points out the great variability of this species, affecting not only the shape of the poles but also other morphologic characters.

Also Quasifusulina eleganta Shlykova has a very long test and shows pointed poles in some specimens. Still, this species has various differences which separate it from the Asiego specimens of Quasifusulina longissima. The most important are a slightly smaller test, greater L/D ratio, more irregular septal folding, smaller proloculum, and more tightly coiled spiral.

Until now, the genus Quasifusulina in the Cantabrian Mountains was known to occur only in the Zone of Montiparus of the Las Llacerias section. The species occurring in that section are considered primitive members of Quasifusulina (see Villa and van Ginkel, 1997). The Asiego specimens, on the other hand, clearly possess the characteristics of highly evolved species of this genus. In addition, with regard to the Cantabrian Mountains, these specimens of Quasifusulina are the largest fusulinacean foraminifers described thus far. According to Watanabe (1996), a morphological variation of the Quasifusulina longissima lineage is observed in the Upper Carboniferous of Japan, being the largest tests (forms belonging to Quasifusulina longissima ultima Kanmera) typical of strata of early Gzhelian age. $Q$. longissima ultima is similar to $Q$. longissima from Asiego in all characters except in the development of the axial fillings, which are slightly weaker in the subspecies described by Kanmera (1958). It could be possible then that the materials from Japan and from Asiego belong to different subspecies, but also that both forms represent the same evolutionary step in the Quasifusulina longissima lineage.

Quasifusulina longissima has both a wide geographic range and long time range. It has been frequently cited in the late Carboniferous and the early Permian of various areas of the euro-asiatic continent (see comments by Isakova, 1978). 


\section{CONCLUDING REMARKS}

The limestone beds of Asiego most probably belong to the top of the Puentellés Formation. This, we believe, shall be confirmed by the present geologic studies in the area.

The fusulinaceans recently discovered in the Asiego beds are of special interest because they are the youngest fusulinacean fauna thus far recorded in the Cantabrian Mountains. One form belongs to the genus Jigulites, which is the first reference to this genus in the Cantabrian Mountains. In addition to Jigulites, the fauna contains the first typical representatives of the genera Rauserites and Quasifusulina.

The association of fusulinacean foraminifera found at Asiego proves for the first time the presence of marine beds of the highest Carboniferous Gzhelian Stage in the Cantabrian Mountains and in the Iberian Peninsula. Considering the most probable affinities of the Jigulites and Rauserites species from Asiego with forms described in other areas, these beds are correlated with the lower Gzhelian.

\section{ACKNOWLEDGEMENTS}

The authors gratefully acknowledge financial support from the projects PB-94-1337 (DGICYT) and IR-98515-1 (University of Oviedo). We also thank Dr. Vladimir Davydov (VSEGEI) who provided useful comments on an earlier version of the manuscript, and the referees Dr. Charles A. Ross (Western Washington University) and Dr. Katsumi Ueno (University of Tsukuba) for the useful suggestions and constructive criticism.

\section{BIBLIOGRAPHY}

Alksne, A. E. 1979. Foraminifery. In: Atlas fauny i flory srednego-pozdnego Karbona Bashkirii (Foraminifera. In: Atlas of the Middle-Upper Carboniferous fauna and flora of Bashkiria ) (Ed. O. L. Einor). Nedra, Moscow, $12-41$.

Bensh, F. R. 1972. Stratigrafiya i Fuzulinidy Verkhnego Paleozoya Yuzhnoy Fergany (Stratigraphy and fusulinids from the Upper Palaeozoic in South Fergana). Tashkent, Izdatel Akademiya Nauk Uzbekistan, SSR (Fan), 146 pp.

Chuvashov, B. N., Leven, E. Ya., Davydov, V. I. et al. 1986. Pogranichnye otlozheniya Karbona i Permi Urala, Priural'ya i Sredney Azii (Biostratigrafiya i Korrelyatsiya) [Carboniferous-Permian boundary beds of the Urals, Pre-Urals and Central Asia (biostratigraphy and correlation)]. Akademiya Nauk SSSR, Uralsky Nauchni Centr, Mosckva Nauka, 151 pp.

Davydov, V. I. 1988. About a phylogenetic criterion of weighing specific features in foraminifer systematics (exemplified by fusulinids). Revue de Paléobiologie, Vol. Spéc. 2, 47-55.

Davydov, V. I. 1990. Clarification of the origin and phylogeny of triticitids and of the boundary of the middle and upper Carboniferous. Paleontological Journal, 2, 39-51 (translated from Paleontologicheskii Zhurnal, 2, 13-25).

Dunbar, C. O. and Condra, G. E. 1927. The Fusulinidae of the Pennsylvanian System in Nebraska. Nebraska Geological Survey Bulletin , 2 (2), 1-135.

Einor, O. L. 1996. The former USSR. Introduction. In: The Carboniferous of the World, Part III (Eds. R. H. Wagner, C. F. Winkler Prins and L. F. Granados). Instituto Tecnológico Geominero de España \& Nationaal Natuurhistorisch Museum, Leiden, 13-23.

Ginkel, A. C. van. 1971. Fusulinids from uppermost Myachkovian and Kasimovian strata of NW Spain. Leidse Geologische Mededelingen, 47, 115-161.

Grigorieva, A. D., Shchegolev, A. K., Alexeeva, I. A. and Shcherbakova, M. V. 1996. Upper Carboniferous and Gzhelian. In: The Carboniferous of the World, Part III (Eds. R. H. Wagner, C. F. Winkler Prins and L. F. Granados). Instituto Tecnológico Geominero de España \& Nationaal Natuurhistorisch Museum, Leiden, 98-122.

Grozdilova, L. P., Lebedeva, N. S., Lipina, O. A., Malakhova, N. P., Mikhailova, Z. P., Chermnych, V. A., Postoyalko, M. V., Simonova, Z. G., Sinicyna, Z. A. and Cherbakova, M. B. 1975. Foraminifery. In: Paleontologicheskiy Atlas Kamennoygol'nykh otlozheniy Urala (Foraminifera. In: Atlas of Palaeontology) (Eds. D. L. Stepanov, et al.). Trudy, VNIGRI, SSSR, 383, 27 64.

Isakova, T. N. 1978. K voprocu o stratigraficheskom znachenii nekotorykh predstabiteley roda Quasifusulina Chen, 1934 (On stratigraphic importance of some representatives of the genus Quasifusulina Chen, 1934). Voprosy Mikropaleontologii, 21, 17-23, pl. I.

Isakova, T. 1986. Otryad Fusulinida. In: Atlas fauny verkhnego Karbona i nizhney Permi Samarskoy Luki (Order Fusulinida. In: Atlas of the Upper Carboniferous and Lower Permian fauna of Samarskaya Luka (Eds. I. S. Muraviev and A. D. Grigorieva). Kazan, Publishing House of Kazan University, 36-62.

Kanmera, K. 1958. Fusulinids from the Yayamadake Limestone of the Hikawa valley, Kumamoto Prefecture, Kyushu, Japan. Part 3: Fusulinids of the Lower Permian. Memoirs Faculty of Sciences, Kyushu University, Ser. D, Geology, 6(3), 153-215.

Konovalova, M. V. 1991. Stratigrafiya i Fuzulinidy Verkhnego Karbona i Nizhney Permi TimanoPechorskoy neftegazonosnoy provintsii (Stratigraphy and fusulinids of the Upper Carboniferous and Lower Permian of the Timan-Pechora oil and gasbearing province). Nedra Publishing House, Moscow, 201 pp.

Lotze, F. 1945. Zur Gliederung der Varisziden der Iberisechen Meseta. Geotektonic Forschungen, 6, 78-92.

Martínez García, E. 1981. El Paleozoico de la Zona Cantábrica oriental (Noroeste de España). Trabajos de Geología, Universidad de Oviedo, 11, 95-127.

Martínez García, E. y Rodríguez Fernández, L. R. 1984. Memoria de la hoja no. 56 (Carreña-Cabrales) del Mapa Geológico Nacional (MAGNA). Instituto Geológico y Minero de España, 1-45.

Martínez García, E. and Wagner, R. H. 1971. Marine and 
continental deposits of Stephanian age in eastern Asturias (NW Spain). Trabajos de Geología, Universidad de Oviedo, 3, 285-305.

Mikhailova, Z. P. 1967. Verkhnekamennougol'nye Fuzulinidy Gryady Chernysheva i zapadnogo sklona Severnogo Ural (Upper Carboniferous Fusulinids from the Chernyshev Ridge and the western slope of Northern Urals). Trudy Instituta Geologii, Akademiya Nauk SSSR, Komi Filial, 6, 29-55.

Miklukho-Maklay, A. D. 1950. Triticites ferganensis sp. nov. iz Verkhnekamennougol'nykh otlozheniy Khrebta Kara-Chatyr (yuzhnaya Fergana) [Triticites ferganensis sp. nov., from the Upper Carboniferous strata of the Kara-Chatyr mountains range (southern Fergana)]. Uchenye Zapiski Leningradskogo Ordena Lenina Gosudarstvennogo Universiteta im A. S. Bubnova, 102(2), 59-70.

Möller, V. von. 1878. Die spiral-gewundenen Foraminiferen des russischen Kohlenkalks. Mémoires de l'Académie Impériale des Sciences de St. Pétersbourg, Russie, ser. 7 , 25(9), 1-147.

Rauser-Chernoussova, D. M. 1938. Verkhnepaleozoyske foraminifery Samarskoy Luki i Zavolzh'ya (Upper Palaeozoic Foraminifera of the Samara Bend and the Trans-Volga region). Akademiya Nauk SSSR, Trudy Geologicheskogo Instituta, 7, 69-167.

Rauser-Chernoussova, D. M., Ivanova, E. A., Grozdilova, L. P. and Makhlina, M. Kh. (in collaboration with Alksne, A. E., Kireeva, G. D., Konovalova, M. B., Meyen, S. V., Morozova, I. P., Rozovskaya, S. E., Faddeeva, I. Z., Shamov, D. F., Shchegolev, A. K. and Shcherbakova, M. V.) 1979. The Upper Carboniferous Series. In: Carboniferous of the USSR (Ed. R. H. Wagner, A. C. Higgins, and S. V. Meyen). Reports presented to the IUGS Subcommission on Carboniferous Stratigraphy at the 8th International Congress on Carboniferous Stratigraphy and Geology, Yorkshire Geological Society, Occasional Publication, 4, 147-174.

Rauser-Chernoussova, D. M., Bensh, F. R., Vdovenko, M. V. 1996. Spravochnik po sistematike Foraminifer Paleozoya (Endotiroidy, Fuzulinoidy) [Reference-book on the systematics of Paleozoic foraminifera (Endothyroidea, Fusulinoidea)]. Nauka Publishing House, Moscow, 207 pp.

Remizova, S. 1995. Foraminifery i biostratigrafiya verkhnego Karbona Severnogo Timana (Foraminifers and biostratigraphy of the Upper Carboniferous of North Timan). Instituta Geologii, Rossiskaya Akademiya Nauk, Uralskoe otdelenie, Komi Nauchni Centr, 128 pp.

Rozovskaya, S. E. 1948. Klassifikatsiya i sistematicheskie priznaki roda Triticites (Classification and systematic characteristics of the genus Triticites). Dokladi Akademiya Nauk SSSR, 59(9), 1635-1637.

Rozovskaya, S. E. 1950. Rod Triticites, ego razvitie i stratigraficheskoe znachenie (The genus Triticites, its development and stratigraphic significance). Trudy Paleontologii Instituta Akademiya Nauk SSSR, 26, 1-78.

Rozovskaya, S. E. 1952. Fuzulinidy verkhnego Karbona i nizhney Permi yuzhnogo Urala (Fusulinids of the Upper Carboniferous and Lower Permian of the southern
Urals). Trudy Paleontologicheskogo Instituta, Akademiya Nauk SSSR, 40, 5-50.

Rozovskaya, S. E. 1958. Fuzulinidy i biostratigraficheskoe raschlenenie Verkhnekamennougol'nykh otlozheniy Samarskoy Luki (Fusulinids and biostratigraphic distribution of Upper Carboniferous deposits of the Samara Bend). Trudy Geologicheskogo Instituta, Akademiya Nauk SSSR, 13, 57-120.

Rozovskaya, S. E. 1975. Sostav, sistema i filogeniya otryada Fuzulinida (Composition, phylogeny and system of the order Fusulinida). Trudy Paleontologicheskogo Instituta, 149, 1-267.

Rotai, A. P. 1979. Carboniferous stratigraphy of the USSR: Proposal for an international correlation. In: Carboniferous of the USSR (Ed. R. H. Wagner, A. C. Higgins, and S. V. Meyen). Reports presented to the IUGS Subcommission on Carboniferous Stratigraphy at the 8th International Congress on Carboniferous Stratigraphy and Geology, Yorkshire Geological Society, Occasional Publication, 4, 225-247.

Solovieva, M. N. 1987. O statuse i ob'eme Schellwienia Staff et Wedekind, 1910 (On the status and volume of genus Schellwienia Staff et Wedekind, 1910). Voprosy Micropaleontologii, 29, 76-77.

Truyols, J., González-Lastra, J., Marquínez, J., MartínezDíaz, C., Méndez-Fernández, C., Menéndez-Alvarez, J. R. and Sánchez de Posada, L. C. 1984. Prelyminary note on two marine sections (Tournaisian-Kasimovian) in the Picos de Europa area (Cantabrian Mountains, NW Spain). Compte Rendu IX International Congress on Carboniferous Stratigraphy and Geology, Urbana 1979, 2, 148-156.

Villa, E. 1995. Fusulináceos carboníferos del este de Asturias ( $\mathrm{N}$ de España). Biostratigraphie $d u$ Paléozö̈que, 13, $261 \mathrm{pp}$.

Villa, E. and Ginkel, A. C. van. 1997. Early schwagerinids and accompanying fusulinid genera from the Kasimovian of the Cantabrian Mountains (Spain). In: Late Paleozoic Foraminifera; their biostratigraphy, evolution, and paleoecology, and the Mid-Carboniferous boundary (Eds. C. A. Ross, J. R. P. Ross and P. L. Brenckle). Cushman Foundation for Foraminifera Research, Special Publication 36, 155-158.

Wagner, R. H. and Martínez García, E. 1998. Floral remains from the highest Valdeón Formation, a marine Stephanian unit south of the Picos de Europa, and comparisons with eastern Asturias, NW Spain. Revista Española de Paleontología, 13, 93-106.

Watanabe, K., 1996. Geographical and stratigraphical distribution of Quasifusulina longissima (Möller) and its allies in Japan and their variations. In: Professor Hisayoshi Igo Commemorative Volume on Geology and Paleontology of Japan and Southeast Asia (Eds. H. Noda and K. Sashida). 99-111.

Watanabe, K. 1997. Quasifusulina longissima longissima (Möller) from Japan and its population in Akiyoshi Limestone Group. Bulletin of the Akiyoshi-dai Museum of Natural History, 32, 85-109.

Manuscrito recibido: 12 de enero, 1998 Manuscrito aceptado: 13 de diciembre, 1998 